\title{
Chapter 2 \\ Halevy and the Historiography of the Talmud
}

\subsection{Introduction}

The desire to write the history of the formation of the Babylonian Talmud (often referred to as the Bavli) gained impetus in the nineteenth century with the foundation of the modern discipline of historical scholarship, both in the German universities and in the Jewish scholarship of Wissenschaft des Judentums and Hokhmat Yisrael. Several Jewish historians published important works addressing the question of the formation of the Talmud, including Heinrich Graetz (Geschichte der Juden, 1853-1875) and Isaac Hirsch Weiss (Dor dor vedorshav, 1871-1891). ${ }^{1}$ These works provided a general account of the process of the Talmud's formation. ${ }^{2}$ As historians, Graetz and Weiss relied on the scant "historical" evidence available: a few germane sources scattered in the Talmud; two early Jewish attempts to reconstruct the rabbinic period, Seder Tannaim ve'amoraim (STVA, ninth century) and the Epistle of Rav Sherira Gaon (tenth century); and a somewhat later one, Abraham ibn Daud's Sefer haqabbalah (twelfth century). ${ }^{3}$ Where possible, Graetz and Weiss also looked to independent corroboration of major events from outside sources. Graetz, for instance, in his analysis of the development of the Talmud in the fourth and fifth centuries (at the time of Abbaye, Rava, and Rav Ashi), drew upon external events in his search for catalysts of the process. As he explained in his History of the Jews, "The period during which the Roman empire was approaching a state of dissolution marks an epoch of decay and regeneration, destruction and rejuvenescence, ruin and reconstruction, in the history of the world." ${ }^{4}$ Graetz saw the world's dominant

\footnotetext{
1 On Graetz, see Heinrich Graetz, Geschichte der Juden von den ältesten Zeiten bis auf die Gegenwart (Leipzig: O. Leiner, 1853-1876), 4:350-352, 4:370-374, and 4:377-378. See also Herman J. Blumberg, "Heinrich Graetz and Ze'ev Jawitz," in The Formation of the Babylonian Talmud: Studies in the Achievements of Late Nineteenth and Twentieth Century Historical and Literary-Critical Research, Studia Post-Biblica 17, ed. Jacob Neusner (Leiden: Brill, 1970). On Weiss, see Weiss, Dor dor vedorshav, 3:183-190; and Shamai Kanter, "I. H. Weiss and J. S. Zuri," in The Formation of the Babylonian Talmud, ed. Jacob Neusner, 11-19.

2 For a summary of their theories, see Julius Kaplan, The Redaction of the Babylonian Talmud (New York: Bloch, 1933), 3-5, 13-19; and Blumberg, "Heinrich Graetz and Ze'ev Jawitz."

3 These sources, particularly STVA and the Epistle, will be discussed and analyzed further below.

4 Heinrich Graetz, History of the Jews from the Earliest Times to the Present Day, trans. Bella Loewy, abr. ed. (Philadelphia, PA: Jewish Publication Society, 1891-1898), 2:604.
}

Ә Open Access. ( 2021 Ari Bergmann, published by De Gruyter. (cc) BY-NC-ND This work is licensed under the Creative Commons Attribution-NonCommercial-NoDerivatives 4.0 International License.

https://doi.org/10.1515/9783110709834-003 
civilization in flux in the fourth century, and these events, in which "barbarian" tribes brought about the fall of the Roman Empire, were catalysts for selfreflection by the Jewish community - and, ultimately, the redaction of the Talmud. In his words, "In this iron time, when no man could be certain of the next day, the leaders of Judaism in Palestine and Babylonia felt deeply the necessity of placing the treasure which had been confided to their hands in safety, so that it might not be imperiled by the accidents of the day. An epoch of collection commenced." ${ }^{5}$ The main problem with these histories was that their nineteenth-century authors were not Talmudists and thus were unable to glean much material from a literary analysis of the talmudic text or from internal evidence. Due to the scarcity of material, their theories lacked sufficient textual evidence and did not withstand critical analysis. ${ }^{6}$ There was no direct evidence for Graetz's imaginative theory of why the rabbis compiled the Talmud, nor, more generally, for the "deep" emotion of which he speaks. It is unclear to what extent the Jewish community in Babylonia was affected by the catastrophes besetting the Roman empire in the fourth century.

Despite the fact that Weiss, unlike Graetz, was a noted talmudic scholar, his internal textual evidence was sparse and weak. For instance, in his analysis of Abbaye, he wrote, based on one story in the Talmud: "This practice [of hairsplitting, interrogating, and retorting] was second nature to him, and he took it to the extreme in debating his colleague Rava. [. . .] In his enthusiasm for pilpul, he rushed to give answers when silence would have been better."7 As discussed in chapter 1, Weiss was an accomplished Talmudist who had studied in prestigious yeshivot and authored important works on two midrashei-halakhah, but his historical work displays similar weakness to Graetz's. Many of his historical assumptions amount to little more than conjecture. About Rava, he remarked, "Indeed, we do not have any clear knowledge about the oppression of Babylonian Jewry at that time, but we do know that Shapur II, who ruled at that time, was not kind to the Jews. Rava was extorted and oppressed by him (Hagigah 5b), so who can say how bitter and terrible was the fate of the Jews in that period [. . .] Furthermore, who knows if after Rava's death their situation worsened?" 8 Weiss based this conclusion on one story in b. Hagigah $5 b$, in which messengers from

5 Graetz, History of the Jews, 2:605.

6 For an analysis of their weaknesses, see Kaplan, The Redaction of the Babylonian Talmud, 5 , 17-19; Blumberg, "Heinrich Graetz and Ze'ev Jawitz," 3-6; and Kanter, "I. H. Weiss and J. S. Zuri," 11-19. Halevy criticizes their findings throughout his work. For examples, see Halevy, Dorot harishonim, 2:198-203, 2:205-210, 3:1-3, and 3:17-19.

7 Weiss, Dor dor vedorshav, 3:176.

8 Weiss, Dor dor vedorshav, 3:179. 
the house of Shapur II sent for Rava and imprisoned him in order to extort money from him. Weiss drew additional conclusions about the Jews' general situation at the time of Rava based on his limited knowledge of the history of that era. Shapur II did engage in religious persecution, mostly of Christians, but also of Jews and Manicheans. ${ }^{9}$ Christian martyrologies portray the Jews as informers against Christians but also martyrs under Shapur II. ${ }^{10}$ The Jews' situation, however, was far better than the Christians' during his rule, since Jews paid their taxes at a time when Christians did not and further supported the government's wars against Rome. ${ }^{11}$ In addition, there is nothing about persecutions in Jewish records until the fifth century. ${ }^{12}$ In The Formation of the Babylonian Talmud, Jacob Neusner describes the shortcomings of the historians of the period, saying that "the evidence they thought relevant was inadequate to answer the question they posed, and reliance on it led them inevitably to inadequate results."13 On the other hand, although scholars of talmudic literature, who concentrated on precise study of the texts using modern critical methods, had made impressive progress in the analysis of the Bavli, their work also left many unanswered questions. Halevy discusses and criticizes one such scholar in particular: the prominent Wissenschaftler Zacharias Frankel, who was discussed in chapter $1 .{ }^{14}$ Frankel's writings focused mainly on the Mishnah and the Palestinian Talmud. ${ }^{15}$ But in one of his

9 For details on Shapur II's persecution of Christians, see Jacob Neusner, "Babylonian Jewry and Shapur II's Persecution of Christianity from 339 to 379 A.D.," Hebrew Union College Annual 43 (1972); and Lee E. Patterson, "Minority Religions in the Sasanian Empire: Suppression, Integration and Relations with Rome," in Sasanian Persia: Between Rome and the Steppes of Eurasia, ed. Eberhard W. Sauer, Edinburgh Studies in Ancient Persia (Edinburgh: Edinburgh University Press, 2017), 187-193.

10 For further details, see Richard N. Frye, "The Political History of Iran under the Sasanians," in The Cambridge History of Iran, vol. 3(1), The Seleucid, Parthian, and Sasanid Periods, Part 1, ed. Ehsan Yarshater (Cambridge: Cambridge University Press, 1983), 139-141. For a detailed analysis of the persecutions, see Josef Wiesehöfer, Ancient Persia: From 550 BC to 650 AD (London: I. B. Tauris, 2001), 204-206.

11 Jacob Neusner, "Jews in Iran," in The Cambridge History of Iran, vol. 3(2), The Seleucid, Parthian, and Sasanid Periods, Part 2, ed. Ehsan Yarshater (Cambridge: Cambridge University Press, 1983), 915.

12 Wiesehöfer, Ancient Persia, 215.

13 Neusner, introduction to The Formation of the Babylonian Talmud, x.

14 Halevy, Dorot harishonim, 2:300.

15 His main works are Darkhei hamishnah (Leipzig: H. Hunger, 1859) and Mevo hayerushalmi: Introductio in Talmud Hierosolymitanum (Breslau: Schletter, 1870). For further discussion of these works, see David Ellenson, "Wissenschaft des Judentums," 4-9; Ismar Schorsch, "Zacharias Frankel and the European Origins of Conservative Judaism,” Judaism 30, no. 119 (1981): 345 and 351-355; and Schorsch, From Text to Context, 255-265. 
few articles on the Babylonian Talmud, he admitted that he did not reconcile the differing accounts found in STVA and the Epistle before proposing a correction to Graetz's periodization of the saboraic era. ${ }^{16}$ As an historical work, Halevy's Dorot harishonim accomplished what Frankel, Graetz, and Weiss could not, combining its author's deep knowledge of the talmudic text with his historical skills.

Though the gaps and shortcomings of the early sources on the history of the Talmud had begun to attract scholarly interest as Wissenschaft des Judentums emerged near the end of the first quarter of the nineteenth century, scholarship on the subject remained incomplete at the end of the century. Scholars at that time lacked a comprehensive theory that would bring together the various sources in a coherent narrative. Central Europe thus provided fertile ground for Halevy simultaneously to demonstrate his scholarly prowess and advance his agenda; he did so by inaugurating his Orthodox Wissenschaft enterprise with Dorot harishonim, a new history of the formation of the Bavli.

\subsection{Background: The structure of the Talmud}

The Babylonian Talmud documents the statements, arguments, and tales of a vast number of sages and serves as the foundational legal and ethical document of rabbinic Judaism. As was mentioned in chapter 1, Maimonides wrote in his introduction to the Mishneh Torah that the greatest sages of Israel were mentioned in the Talmud, and that the Talmud's laws were obligatory for Jews to follow. ${ }^{17}$ The Bavli is commonly described as a commentary on the Mishnah, but its nature is more complex than the term "commentary" would imply. Although it takes the Mishnah as a starting point, the text evolves into an exploration of myriad

16 Zacharias Frankel, “Beiträge zu einer Einleitung in den Talmud,” Monatsschrift für Geschichte und Wissenschaft des Judentums 10, no. 7 (1861): 258-267. On Frankel and the Mishnah, see Shamma Friedman, "Zacharias Frankel and the Study of the Mishnah" [in Hebrew], in From Breslau to Jerusalem: Rabbinical Seminaries. Past, Present, and Future [in Hebrew] (Jerusalem: Leo Baeck Institute, 2009). See below and chapters 3 and 4 for more details on the questions surrounding the periodization of this and other rabbinic eras.

17 On Maimonides's view of the Bavli, see Shamma Friedman, "The Rambam and the Talmud" [in Hebrew], Dinei Israel 26-27 (2009-2010); Gerald J. Blidstein, “Where Do We Stand in the Study of Maimonidean Halakhah?” in Studies in Maimonides, ed. Isadore Twersky, Harvard Judaic Texts and Studies 7 (Cambridge, MA: Harvard University Center for Jewish Studies, 1990); Jacob S. Levinger, Darkhei hamahashavah hahilkhatit shel harambam: Mehqar al hametodah shel Mishneh Torah (Jerusalem: Magnes Press, 1965), 155-189; and Hanina BenMenahem, "The Second Canonization of the Talmud," Cardozo Law Review 28, no. 1 (2006): 46-51. 
subjects, incorporating discussions on a vast array of topics. It not only contains legal discussions and rulings of the Amoraim (the rabbis of Babylonia beginning in the third century) but also presents their worldview. It draws upon the totality of earlier rabbinic teachings and traditions, starting from the late-Second-Temple period in the second century BCE and extending to the teachings of the Tannaim (the rabbinic sages active from the first century CE until the completion of the Mishnah in the early third century CE). It further incorporates the contemporaneous teachings of the Amoraim of Palestine. The Bavli thus represents the culmination of the rabbinic enterprise of the talmudic period, which began in the early third century after the compilation of the Mishnah (compiled, according to the Talmud, by Rabbi Yehudah Hanasi). ${ }^{18}$ As a result, it has been assiduously studied, interpreted, and debated by the Jewish community up to the present day. In the words of Ephraim Urbach: "The process which fused the decisions, halakhot [legal rulings], and sevarot [logical deductions] of sages and scholars from generation to generation created a collective authority which can be seen as the sum total of the recognition enjoyed by those sages and scholars."19 The collective nature of the Talmud and its gradual development over centuries gives the Talmud its supreme authority, as it represents the combined wisdom of all the rabbinic authorities cited therein.

The Bavli underwent a gradual process of formation across generations of sages. There is much debate regarding the periodization of this process, as will be discussed in more detail in chapters 3 and 4. It is generally agreed, however, that the tannaitic period (whose scholars are called "Tannaim," from the Aramaic word "tanna," meaning "scholar" or "teacher") spanned the approximately 200 years before the codification of the Mishnah in Palestine in the early third century CE. ${ }^{20}$ The Tannaim were followed by the Amoraim (Hebrew and Aram., "interpreters" or "reciters"). Until about 500 CE, the Amoraim commented on the Mishnah and the contemporaneous but less canonical Tosefta (Aram., "addition"). They worked in Palestine, especially in Tiberias, Sepphoris, and Caesaria, and in Babylonia, especially in Nehardea, Sura, and Pumbedita. ${ }^{21}$ The Saboraim (Aram., "reasoners," or "those who reflect") were the Babylonian scholars who

18 For more details, see Barry Scott Wimpfheimer, The Talmud: A Biography, Lives of Great Religious Books (Princeton, NJ: Princeton University Press, 2018), 9-39.

19 Ephraim Elimelech Urbach, The Halakhah: Its Sources and Development (Masada: Yad LaTalmud, 1986), 347.

20 Encyclopaedia Britannica Online, academic ed., s.v. “Tanna,” accessed 19 March 2020, https:// www.britannica.com/topic/tanna-Judaic-scholar.

21 Encyclopaedia Britannica Online, academic ed., s.v. “Amora,” accessed 20 March 2020, https:// www.britannica.com/topic/amora. 
operated between the Amoraim and the Geonim. ${ }^{22}$ Very little is known about the saboraic period, which is one reason why Halevy devoted a significant part of his history to identifying the Saboraim and their contributions to the Talmud. From the seventh to the thirteenth centuries CE, with many disruptions due to the political situation in the Near East, the Geonim (sing., Gaon; Hebr., "excellencies") headed the talmudic academies and developed talmudic law by interpreting the Talmud and settling disputes regarding its interpretation and application. $^{23}$

As a result of the gradual nature of its formation, the Bavli consists of multiple literary strata. Its most characteristic literary form is the sugya (plural, sugyot). The sugya is a dynamic, free-flowing literary unit that usually contains material representing three layers. The discussion often begins with material from a tannaitic layer consisting of baraitot (sing., baraita, from the Aramaic bar, outside; tannaitic teachings not included in the Mishnah) or quotes from the Mishnah; an amoraic layer, consisting of meimrot (statements) and other amoraic traditions, which often comments and expands upon the tannaitic material; and, finally, a later, editorial layer of anonymous dialectical material known as setam hatalmud (henceforth, "the setam"), which frames and organizes the dialectical argument. ${ }^{24}$

The sugya in b. Yevamot 62a is a good example of this literary unit in the Talmud:

[A] It is taught in a baraita: Rabbi Nathan says [that] Beit Shammai say: "[The mitzvah to be fruitful and multiply in Genesis 1:28 is fulfilled with] two males and two females," and Beit Hillel say: "A male and a female."

[B] Rav Huna said: "What is the reason of Rabbi Nathan, in accordance [with the opinion] of Beit Shammai? As it is written: 'She then bore his brother [et ahiv]

22 Daniel Sperber, "Savora, Savoraim," in Encyclopaedia Judaica, 2nd ed., ed. Michael Berenbaum and Fred Skolnik (Farmingdale, MI: Macmillan Reference, 2007), accessed 29 June 2020, https:// yulib002.mc.yu.edu:2821/apps/doc/CX2587517589/GVRL?u=nysl_me_yeshival\&sid=GVRL\&xid= 77 eea0d8.

23 Encyclopaedia Britannica Online, academic ed., s.v. “Gaon,” accessed 20 March 2020, https://www.britannica.com/topic/gaon.

24 On the amoraic layer and the setam, see Shamma Friedman, "A Critical Study of Yevamot $\mathrm{X}$ with a Methodological Introduction" [in Hebrew], in Texts and Studies: Analecta Judaica I (New York: Jewish Theological Seminary, 1977), 283-308. On the tannaitic layer, see Judith Hauptman, "The Three Basic Components of the Sugya: The Tannaitic Passages, the Amoraic Statements, and the Anonymous Commentary" [in Hebrew], in Melekhet Mahshevet: Studies in the Redaction and Development of Talmudic Literature [in Hebrew], ed. Aharon Shemesh and Aaron Amit (Ramat Gan: Bar-Ilan University Press, 2011), 39-45. 
Abel [et Hevel]' (Gen. 4:2). ${ }^{25}$ [The apparently superfluous et indicates that she gave birth to] Abel and his sister [in addition to] Cain and his sister. And it states, 'God has provided me with another offspring in place of Abel'” (Gen. 4:25).

[C] And the rabbis [Beit Hillel] - [how do they understand this verse? In their opinion, Eve] was [just] thanking God [for granting her another child, but not implying an obligation to have two additional children]. ${ }^{26}$

Section [A], the tannaitic layer, starts with, "It is taught" and quotes a baraita (in this case, regarding the biblical verse, "Be fruitful and multiply"). Section [B] quotes a meimra, a statement of the Amora Rav Huna explaining the baraita and its reasoning (in this case, the reasoning of Beit Shammai). Section [C] is the setam, the editorial layer of anonymous material, which completes the dialectical argument by explaining the opposing view (in this case, Beit Hillel's, regarding the meaning of the verse, "Be fruitful and multiply"). The anonymous stratum constitutes most of the talmudic material and also creates the framework of the sugya into which the attributed amoraic statements are inserted.

The basic structure of the Talmud is, therefore, essentially anonymous, which is rather ironic, since the Talmud usually extols attribution. The statement in b. Megillah 15a - "whoever reports [a ruling] in the name of its originator brings deliverance into the world, as it says 'and Esther told the king in the name of Mordechai'” [Esther 2:22] - is indicative of this tradition. ${ }^{27}$ In addition, according to the eminent Talmudist and scholar David Weiss Halivni, the authority of any given statement is connected to "the individual Amora" who said it; the Talmud's teaching "bears no collective authority."28

The amoraic layer and the setam are the main components of most talmudic sugyot, and they thus have been the subject of much study since Halevy's time. The critical study of the Bavli has greatly developed in the last century. Talmudic scholars such as Halivni and Shamma Friedman have developed theories about the nature and the unique genre of the setam, and the distinction between these two primary literary strata has become the cornerstone of the

25 All translations of the Tanakh follow the 1985 New Jewish Publication Society (NJPS) translation.

26 My translation, based on Ms. Vatican 110.

27 The Talmud's praise of attribution is reflected in other passages in the Bavli as well. See examples in m. Avot 6:1, b. Hullin 104b, and b. Niddah 19b. See also David Weiss Halivni, Meqorot umesorot leseder Mo'ed from Yoma until Hagiga (Jerusalem: Jewish Theological Seminary, 1975), 5.

28 David Weiss Halivni, Midrash, Mishnah, and Gemara: The Jewish Predilection for Justified Law (Cambridge, MA: Harvard University Press, 1986), 67. 
academic study of the Talmud. The primary challenge for the reader is to differentiate between the attributed statements of the Amoraim and the anonymous setam discussion surrounding the amoraic dicta. ${ }^{29}$ As Halivni notes, this distinction is of utmost significance, since in many instances the two strata have different degrees of authority or veracity. The attributed statements of the Amoraim have perhaps more authority and are more reliable than the setam. Halivni's view, therefore, is that in any instance in which the setam's explanation is clearly incorrect or forced, an alternative interpretation can be found; the attributed amoraic statements, on the other hand, are not subject to debate. ${ }^{30}$ Although Halivni's view about the lower authority and veracity of the setam differs from those of Halevy and others, as will be discussed in chapter 4, the distinction between these two layers is significant, as the setam clearly represents a diverse genre and has a different level of authority than the attributed amoraic statements. In his introduction to Halivni's The Formation of the Babylonian Talmud, Jeffrey L. Rubenstein provides some guidance in differentiating the two layers: "These strata differ in form and style: Amoraic dicta (meimrot) are brief and 'apodictic' - a term Halivni borrows from biblical studies, and by which he means both terse and categorical. These typically consist of pronouncements of legal rulings or succinct explanations of an earlier source. The anonymous Talmud, by contrast, is verbose, expansive, and contains the Talmud's intricate and complex dialectical argumentation. It may include [sic] series of objections, solutions, rhetorical questions, and contrived and spurious propositions, sometimes extending over a full folio or more."31 Rubenstein goes on to explain that although these two strata differ in form and style, it is still not always easy for the reader to differentiate between material from the Amoraim and material that we would attribute to the setam. Although it is useful to notice that the apodictic material of the Amoraim is often written in Hebrew, while the anonymous stratum is primarily in Aramaic, these distinctions are not absolute. Scholars have, in fact, come to different conclusions on

29 Halivni notes that these terms (setamma degemara and setamma detalmuda) are not found in the writings of the Geonim but are commonly used by the twelfth-century Ashkenazic (western European) commentators, such as Tosafot and Rabbi Asher ben Jehiel (ca. 1250-1327). See David Weiss Halivni, Mevo'ot lemeqorot umesorot: Iyyunim behithavut hatalmud (Jerusalem: Magnes Press, 2012), 42.

30 David Weiss Halivni, The Formation of the Babylonian Talmud, trans. and ed. Jeffrey L. Rubenstein (Oxford: Oxford University Press, 2013), 202.

31 Jeffrey L. Rubenstein, translator's introduction to Halivni, The Formation of the Babylonian Talmud, xxi-xxii. 
this point. ${ }^{32}$ At times the setam is short (as in the above sugya), just expanding and concluding amoraic statements to include opposing views. At other times, the setam is long, extending over at least one folio, posing challenges and proposing solutions, setting up the Talmud's dialectical argumentation by bringing the various decisions into conversation and debate. The differing histories of these two strata, in addition to their distinct natures, have provided a key element in the understanding of the structure of the Talmud, but the correct interpretation of these differences is far from a settled matter and has been the subject of fierce debate over the past two centuries. Halevy was literarily perceptive and sensitive to the nuances of the talmudic text, and thus his historiography aimed to address precisely how these diverse components developed.

\subsection{The sources available to Halevy}

Despite the Bavli's central role in rabbinic Judaism, the history of its formation is elusive and remains subject to scholarly debate. Very little direct evidence can be found to answer the major questions concerning the Talmud's textual development and redaction, and even indirect evidence is scarce. Although the Mishnah does not discuss its editing process, either, it is clear that Rabbi Yehudah Hanasi (the Prince) played a leading role; several talmudic passages refer to him as the editor of the Mishnah. ${ }^{33}$ No such information is available for the Babylonian Talmud's redaction and editing, with the exception of a brief statement found in b. Bava Metzi'a 86a: "Rav Ashi and Ravina - the end of hora'ah.” This ambiguous dictum - and the meaning of the term "hora'ah," which comes from a root meaning "teach/instruct" - does not describe or explain a redaction or editing process, as will be discussed in more detail in chapters 3 and 4 .

In writing his history of the formation of the Babylonian Talmud in Dorot harishonim, therefore, Halevy had few previous historical works on which to rely. The primary genre of scholarship produced by Jewish writers from the geonic

32 Hyman Klein argued that the anonymous dialectical material is exclusively written in Aramaic, with the exception of technical Hebrew expressions. See Hyman Klein, "Gemara and Sebara," Jewish Quarterly Review 38, no. 1 (July 1947): 75-76 and 91. Initially, Shamma Friedman's position on the subject was similar to Klein's, but it has evolved over time. See Shamma Friedman, “'Wonder Not at a Gloss in Which the Name of an Amora is Mentioned': The Amoraic Statements and the Anonymous Material in the Sugyot of the Bavli Revisited" [in Hebrew], in Melekhet Mahshevet, ed. Aharon Shemesh and Aaron Amit. See also Friedman, “A Critical Study of Yevamot X" [in Hebrew], 301-302 and 301n60.

33 See Halivni, The Formation of the Babylonian Talmud, 103, 103n88, and the literature cited there. 
period to the sixteenth century is called shalshelet haqabbalah ("the chain of tradition" of the Oral Law). Works in this genre detail the chronology of the sages who transmitted the Oral Law [Torah sheba'al peh]. As Yosef Hayim Yerushalmi notes in Zakhor, his influential work on Jews' relationship to the practice of history in the Middle Ages, shalshelet haqabbalah literature's "purpose was to establish and demonstrate an unbroken succession of teaching and authority from the Bible, through the Talmud, and often up to the time of the author himself." 34 Its writers' interest was focused almost entirely on the relationship of talmudic literature to earlier rabbinic law. They were not historians because Rabbinic Judaism throughout the ages generally had very little interest in historiography: "the many compositions of this type [shalshelet haqabbalah] did not come into being out of a desire to write or interpret the history of the Jewish people. Their chief impulses lay elsewhere - in the need to refute those heretics from within and adversaries from without who denied the validity of the Oral Law, in the practical need to determine points of jurisprudence according to earlier or later authorities, and perhaps also in a natural curiosity about the progress of rabbinic scholarship." 35 There are thus few biographical details about the sages, and when historical events appear, they often seem to be mentioned for no particular reason. ${ }^{36}$ Yerushalmi argued that, for the rabbis, what counted was the meaning of the Jewish people's history. This was an ideological position; as Yerushalmi writes, "far from indicating a gap in their civilization, it may well reflect a self-sufficiency that ours no longer possesses."37 As a result of this attitude, their account of the process of the formation of the Talmud is neither comprehensive nor fully developed.

Despite the obvious shortcomings of shalshelet haqabbalah literature, this chapter will introduce its main texts because Halevy read and considered them in the process of his own historical analysis - as did many of his contemporaries, and as some talmudic scholars still do today. In his seminal work The Geonim of Babylonia and the Shaping of Medieval Jewish Culture (1998), Robert Brody also extensively employed these accounts to reconstruct the era. In his words, "The works were also the mainstay - and practically the only trustworthy sources - of Jewish scholars of the nineteenth century, who attempted for the first time to describe the history of the Geonic period in accordance with modern historical methods and standards." 38 He further remarked, "We need not agree with all of

\footnotetext{
34 Yerushalmi, Zahhor, 31.

35 Yerushalmi, Zahhor, 32.

36 Yerushalmi, Zakhor, 31.

37 Yerushalmi, Zakhor, 34.

38 Brody, The Geonim of Babylonia and the and the Shaping of Medieval Jewish Culture (New Haven, CT: Yale University Press, 1998), 20.
} 
Sherira [Gaon]'s evaluations and preferences, but the data he provides are invaluable." ${ }^{39}$ It is not surprising that Halevy, writing at the end of the nineteenth century and into the twentieth, also relied on these accounts to describe the saboraic and geonic eras.

Other more recent scholars have defended Rav Sherira's methods, or those like his, as well. Isaiah Gafni (b. 1944) has remarked that within Rav Sherira's chronology, there are many novel historical narratives, including about the talmudic period, and these narratives tell a vital story. As he explains, "the talmudical historical narrative of Rav Sherira is the work of an historian who seeks to logically connect data that survived independently. One modern scholar of historical narrative asserted that 'histories . . . are not only about events but also about the possible sets of relationships that those events can be demonstrated to figure." "40 His view is based on Hayden V. White's theory about the importance of narrative in historiography: "Histories [. . .] are not only about events but also about the possible sets of relationships that those events can be demonstrated to figure. These sets of relationships are not, however, immanent in the events themselves; they exist only in the mind of the historian reflecting on them."41 Shalshelet haqabbalah literature fits that description extremely well, and thus its relevance as historiography should not be underestimated. Although narrative is not always explicit in chronicles, their chains of events are valuable descriptions of historical realities. As White further explained, "I treat annals and chronicle forms of historical representation, not as [sic] imperfect histories they are conventionally conceived to be, but rather as particular products of possible conceptions of historical reality, conceptions that are alternatives to, rather than failed anticipations of, the fully realized historical discourse that the modern history form is supposed to embody." 42 Rav Sherira's Epistle is important both because it reflects his "conceptions of historical reality" and because the work influenced many others' conceptions of the amoraic, saboraic, and geonic periods, from Rashi to Halevy to Gafni and beyond.

39 Brody, The Geonim of Babylonia, 25.

40 Isaiah Gafni, "On Talmudic Historiography in the Epistle of Rav Sherira Gaon: Between Tradition and Creativity" [in Hebrew], Zion 73, no. 3 (2008): 293. The quotation is from Hayden V. White, Tropics of Discourse: Essays in Cultural Criticism (Baltimore: The Johns Hopkins University Press, 1986), 94. Gafni provides the original English of this and other White quotations in the footnotes (in this case, 293n100).

41 White, Tropics of Discourse, 94, quoted in Gafni, "On Talmudic Historiography in the Epistle" [in Hebrew], 293n100.

42 Hayden V. White, The Content of the Form: Narrative Discourse and Historical Representation (Baltimore: The John Hopkins University Press, 1987), 5-6. 
In the remainder of the chapter, for the sake of clarity, some more recent scholarship on these works will be included even though Halevy did not have access to it. The chapter will conclude with a brief summary of Halevy's views of these texts.

\subsubsection{Seder Tannaim ve'amoraim (STVA)}

The earliest-known account of the history of the Bavli's formation is found in Seder Tannaim ve'amoraim (Order of the Tannaim and Amoraim), which was composed ca. $886 \mathrm{CE}$, during the geonic period. ${ }^{43}$ At that time, Hayya ben Nahshon was Gaon (head of the academy) of Sura, and Tsemah ben Paltoy was Gaon of Pumbedita. ${ }^{44}$ Sura and Pumbedita were the best-known of the formally organized talmudic learning academies, named after neighboring towns near the site of ancient Babylon. By the end of the ninth century, both had moved to Baghdad but continued to be called by the names of the towns where they had been founded. ${ }^{45}$ These academies were well-established hierarchical institutions. The Geonim, as the heads of these academies, fulfilled many communal roles and exerted tremendous influence over the entire Jewish world. They had administrative jurisdiction over many territories, and their moral authority extended throughout the Jewish communities outside Palestine. Their influence over those communities stemmed mainly from their writing of responsa, which addressed either questions of practical halakhah or academic queries concerning the interpretation and correct version of talmudic texts. ${ }^{46}$ In geonic times, unlike during talmudic times, these responsa became a central tenet of rabbinic activity. After the Muslim conquests of the seventh century, most of the Jews in the world were ruled by a single cultural and political entity for the first time in over 1,000 years. Geonic responsa writing became even more active during the

43 Kalman Kahana, ed., Seder Tannaim weAmoraim auf Grund mehrerer veröffentlicher und nicht veröffentlicher Texte bearbeitet (Frankfurt am Main: Hermon, 1935), 7.

44 Shraga Abramson, "The Textual History of Seder Tannaim ve'amoraim" [in Hebrew], in Studies in Rabbinic Literature, Bible, and Jewish History: Ezra Melamed Jubilee Volume [in Hebrew], ed. Yitzhak D. Gilat, Chaim Y. Levine, and Zvi Meir (Ramat Gan: Bar-Ilan University Press, 1982), 217; Brody, The Geonim of Babylonia, 344.

45 Brody, The Geonim of Babylonia, 36. For more details on these academies, see David Goodblatt, "The History of the Babylonian Academies," in The Cambridge History of Judaism, vol. 4, The Late Roman-Rabbinic Period, ed. Steven T. Katz (Cambridge: Cambridge University Press, 2006); Isaiah Gafni, "Yeshiva and Metivta" [in Hebrew], Zion 43, no. 1-2 (1978); and Jeffrey L. Rubenstein, "The Rise of the Babylonia Rabbinic Academy: A Reexamination of the Talmudic Evidence," Jewish Studies: An Internet Journal (JSIJ) 1 (2002).

46 Brody, The Geonim of Babylonia, 187-188. 
Abbasid dynasty, when Babylonia became the center of the Islamic empire. ${ }^{47}$ The Geonim were virtually the only ones authoring these responsa, although they responded in the name of all the scholars of the academy. ${ }^{48}$ The Gaon was thus the ultimate spokesman of the great academies of Babylonia and came to represent their decisive influence over all Jewish communities outside Palestine. The queries addressed to them also provide valuable historical information about the geonic era, as the questioners described their problems as fully as possible, although many of the legally irrelevant details were later omitted by scribes and other users. ${ }^{49}$

The identity of STVA's author is unknown, and scholars still debate its attribution. The rabbinic scholar Shraga Abramson (1914-1996) of Hebrew University believed the work to be of Suran origin. ${ }^{50}$ Halevy was of the same view. ${ }^{51}$ More recently, however, Robert Brody has seen no logical reason for this conclusion. ${ }^{52}$ STVA is divided into two parts: a historical section and a methodological section. The historical section describes the chain of transmission of rabbinic tradition, i.e, shalshelet haqabbalah, from the biblical patriarchs, who were assumed to have observed some rabbinic laws, through the middle of the third century CE. It then shifts its focus to the chain of transmission in Babylonia during the next three centuries, starting with the departure of Rav, the first Amora, from Palestine to Babylonia. Its chronology then includes a list of the dates of death of the prominent Babylonian Amoraim and Saboraim, after which it uses a formula to calculate the date of the work from the time of creation, yielding a date in the 880s CE. Then there is a list of the Tannaim and the scholars who came before them, starting with Simeon the Righteous of the Great Assembly. Finally, in a concluding section, the author adds a third historical passage, which lists both Tannaim and Amoraim by generation, from the time of Hillel and Shammai (first century BCE) to the time of Rav Ashi and Ravina (fifth century CE). ${ }^{53}$ The chronology extends beyond that date, although the text relating to the sages beyond the fifth century may have been added by a different author, possibly at a later point than the rest of the text. $^{54}$ The methodological section contains some remarks on the chronology of

47 Brody, The Geonim of Babylonia, 185.

48 Brody, The Geonim of Babylonia, 60-61.

49 Brody, The Geonim of Babylonia, 189. For further details on the contents and style of the questions and responsa, or she'elot uteshuvot, see Brody, 190-193.

50 Abramson, “The Textual History of Seder Tannaim ve'amoraim” [in Hebrew], 217.

51 Halevy, Dorot harishonim, 3:55.

52 Brody, The Geonim of Babylonia, 9-10.

53 Brody, The Geonim of Babylonia, 274-275.

54 Brody, The Geonim of Babylonia, 275n30. 
the Amoraim and the identities of rabbis who are frequently quoted in an abbreviated or indeterminate form, i.e., in anonymous statements in the Mishnah, baraitot, and other tannaitic writings. The section also discusses how to determine the identities of sages when several share the same name (such as Rabban Gamliel), or when sages are called by their monikers. The sages' identities are followed by observations concerning the time and place in which they were active. STVA then lists rules for deciding the correct halakhah in various cases of disputes between the sages. ${ }^{55}$ Adding to the confusion, there are two distinct chronologies, and, in the second one, the chronological order is maintained for the Tannaim but not for the Amoraim. ${ }^{56}$

Given these chronological issues, it is highly doubtful that STVA was the work of only one author. ${ }^{57}$ Brody writes that because of the confusing nature of the work, it is not clear that the date in the 880s CE for the work's composition refers to the entire work we now have. ${ }^{58}$ Therefore, STVA is of doubtful attribution and accuracy. Its account is confusing and, in many instances, unintelligible, though Brody argues that Abramson overemphasized the incoherence of the text. ${ }^{59}$ There is a critical edition of STVA from the 1930s, but a fully annotated modern critical edition has yet to be produced. ${ }^{60}$

\subsubsection{The Epistle of Rav Sherira Gaon (Iggeret Rav Sherira Gaon)}

The second-oldest, and by far the most accurate and extensive, account of the talmudic and geonic period is the Epistle of Rav Sherira Gaon ("the Epistle"). ${ }^{61}$ Rav Sherira, Gaon of Pumbedita (906-1006), wrote it in 986 CE (1298 of the Seleucid Era, according to the calendar employed in geonic times) in response to a series of questions addressed to him by the community of Qayrawan (present-

55 Brody, The Geonim of Babylonia, 275.

56 Abramson, "The Textual History of Seder Tannaim ve'amoraim" [in Hebrew], 217.

57 Abramson, "The Textual History of Seder Tannaim ve'amoraim" [in Hebrew], 217-218; Brody, The Geonim of Babylonia, 276.

58 Brody, The Geonim of Babylonia, 276.

59 Brody, The Geonim of Babylonia, 276.

60 The critical edition is Kahana, ed., Seder Tannaim weAmoraim. Regarding the lack of a modern critical edition, see Abramson, “The Textual History of Seder Tannaim ve'amoraim” [in Hebrew], 217n1; and Robert Brody, "On the Sources for the Chronology of the Talmudic Period” [in Hebrew], Tarbiz 70, no. 1 (2001): 76.

61 Brody, The Geonim of Babylonia, 21-22; Jacob E. Efrati, The Sevoraic Period in Babylonia and Israel: 500-689 [in Hebrew] (Petah Tiqvah: Agudat Benei Asher, 1973), 1. 
day Tunisia). ${ }^{62}$ The last question concerns the saboraic rabbis: "How were they ordered after Ravina, and which heads of the academies reigned after them, and for how many years did they reign, from then until now?" ${ }^{3}$ In his response, Rav Sherira expanded the scope of the question and included information concerning the history of the amoraic era. Brody notes, "Although Sherira does not say so, he may also have seen this as an excellent opportunity to stress the great antiquity and glorious heritage of the Babylonian academies, and particularly his own academy of Pumbedita." ${ }^{64} \mathrm{He}$ also addressed the formation of the Talmud and discussed the Saboraim twice in his response: once in the context of literary history, regarding their contribution to the process of the formation of the Talmud, and once in the context of institutional history, regarding their status as contemporaries of the early Geonim. ${ }^{65}$ Rav Sherira further noted the existence of misinformation regarding the talmudic period. (Jewish scholars of the nineteenth and much of the twentieth century thought that Rav Sherira wrote the Epistle at least in part in defense of rabbinic tradition against Karaite criticism, as Benjamin M. Lewin discussed in the introduction to his critical edition of the Epistle. Now, however, there is a scholarly consensus that the questions by the community of Qayrawan that Rav Sherira attempted to answer in the Epistle were typical of the inquiries that interested the rabbanite intellectuals of Qayrawan. $)^{66}$ Brody argues that it is possible that Rav Sherira composed the Epistle because the questioners from Qayrawan believed that STVA provided sufficient sources on the amoraic period, and Rav Sherira felt it necessary to counter that work, even indirectly. ${ }^{67}$

Due to the fact that Rav Sherira was the Gaon of the academy of Pumbedita, some scholars have suggested that the Epistle presents the Pumbeditan view of

62 This information is contained in the heading of the Epistle in various manuscripts. See Brody, The Geonim of Babylonia, 20n4; and Benjamin Manasseh Lewin, ed., Iggeret Rav Sherira Gaon: Mesuderet bishnei nusahot. Nusah Sefarad venusah Tsarfat im hilufei girsa'ot mikol kitvei hayad vekitvei hagenizah sheba'olam (Haifa: G. Itzkowsky, 1921), 2-4. On the Seleucid calendar as the preferred method of chronology during the geonic period, see Brody, $7 \mathrm{n} 17$.

63 Lewin, ed., Iggeret Rav Sherira Gaon, 6. See also Brody, The Geonim of Babylonia, 10.

64 Brody, The Geonim of Babylonia, 20-21. The quotation from Brody is on page 21.

65 See Brody, The Geonim of Babylonia, 4-5.

66 For Lewin's account, see his introduction to his edited Iggeret Rav Sherira Gaon, v-xvii. On the current consensus, see Brody, The Geonim of Babylonia, $20 \mathrm{n} 5$.

67 See Brody, The Geonim of Babylonia, 21n6. For the instances in which the Epistle directly contradicts STVA, see David Goodblatt, Rabbinic Instruction in Sasanian Babylonia, Studies in Judaism in Late Antiquity 9 (Leiden: Brill, 1975), 36-37; and Isaiah Gafni, The Jews of Babylonia in the Talmudic Era: A Social and Cultural History [in Hebrew], Monografiyot betoledot Am Yisrael (Jerusalem: Shazar, 1990), 246-247. 
Babylonian Jewish history. ${ }^{68}$ This perspective would explain Rav Sherira's failure to provide a specific account of the activities of the academy of Sura in the early sixth century, as well as for his dating of the end of the saboraic period. It is evident from the Epistle that Rav Sherira dates the beginning of the geonic period to no later than 588-589 CE (900 on the Seleucid calendar). Thus, the saboraic period would have ceased several years earlier, with the two periods separated by a time of persecutions. ${ }^{69}$ In the nineteenth century, Abraham Epstein suggested that perhaps this dating was the Pumbeditan version of the transition, while the Suran version would date it a century or more later, to after the rise of Islam. ${ }^{70}$ He draws this conclusion from a mention in STVA that dates the chronology of the last of the Saboraim to after the rise of Muhammad. ${ }^{71}$ Both Brody and Gerson Cohen, however, have challenged his assertion. ${ }^{72}$ Furthermore, Brody notes that the passage in STVA is problematic, as it dates the rise of Muhammad to the year 516-517 CE, almost a century earlier than when it occurred. ${ }^{73}$ Moreover, as will be discussed in chapter 4, the transition from the saboraic era to the geonic era was not a single unique event but, rather, a process that spanned a long term, as evidenced by the fact that some sages even in the later geonic era had the title of Sabora. ${ }^{74}$ In various instances, moreover, enactments of the Geonim were referred to as saboraic. ${ }^{75}$ Thus the various dates of the transition do not reflect different academies or traditions as the source, but, rather, various stages in the process. Brody has argued, therefore, that there is no good reason to question the accuracy of Rav Sherira's account of the events and chronology of the sixth

68 Brody, The Geonim of Babylonia, 9-10.

69 See Lewin, ed., Iggeret Rav Sherira Gaon, 99-100.

70 See Abraham Epstein, Of the Jewish Antiquities: Studies and Monographs [in Hebrew], ed. Abraham M. Haberman (Jerusalem: Mossad Harav Kook, 1965), 410-413. For a further discussion of the topic, see Abraham Ibn Daud, The Book of Tradition: Sefer Ha-Qabbalah, ed. Gerson D. Cohen (Philadelphia, PA: Jewish Publication Society, 1967), 181-186. See also Brody, The Geonim of Babylonia, 8-11.

71 Kahana, ed., Seder Tannaim weAmoraim, 7.

72 Ibn Daud, The Book of Tradition, ed. Cohen, 186; Brody, The Geonim of Babylonia, 10.

73 Brody, The Geonim of Babylonia, 10.

74 For such an instance, see Binyamin M. Lewin, ed., Otsar hageonim: Teshuvot Geonei Bavel uperushehem al-pi seder hatalmud, vol. 12, Bava Qamma (Jerusalem: Mossad Harav Kook, 1940), 57 (section 186).

75 Two examples are the famous enactment of the rebellious wife [moredet], described by Suran Gaon Rav Natronai b. Hilai as saboraic, and the first sugya in b. Qiddushin, described by Rav Sherira as authored by Saboraim. This phenomenon will be discussed in chapter 4. See also Brody, The Geonim of Babylonia, 9-10. 
century. It is very unlikely that the two academies had developed different conceptions of post-talmudic history. ${ }^{76}$

Rav Sherira relies on a variety of sources, and scholars debate whether the Epistle should be considered an independent chronological source, or whether Rav Sherira used STVA as a source. ${ }^{77}$ Brody argues that the chronology of the Epistle is in some cases similar to that given in STVA, while in others it varies considerably. ${ }^{78}$ He thus proposes that STVA and the Epistle shared a common third source. According to this model, Rav Sherira and the author of STVA each completed their chronology based on this third source, which has since been lost. ${ }^{79}$ In Brody's opinion, the lost source was of Suran origin and included a chronicle of the Amoraim until the death of Rav Ashi (fifth century CE) and perhaps beyond. This source may even have been the origin of the Epistle's chronology of the academy of Sura during the early saboraic era. ${ }^{80}$ Brody believes that such a chronicle, spanning a period of over 200 years, is not the product of an individual but, rather, of an established institution, perhaps the exilarchate. ${ }^{81}$

Brody's theory, if correct, enhances the Epistle's credibility in its account of the amoraic period. Before Brody presented his ideas, it was assumed that Rav Sherira's knowledge of that period and of the general evolution of talmudic literature stemmed principally from his interpretation of talmudic sources, and scholars debated whether Rav Sherira had had access to reliable non-talmudic sources. The Epistle frequently cites talmudic sources but hardly mentions other sources on the period. Brody writes that it is unclear whether Rav Sherira failed to cite other sources because his most important sources were talmudic, or because his readers only had access to talmudic, and not extra-talmudic,

76 Brody, The Geonim of Babylonia, 9-10.

77 Heinrich Graetz believed that Rav Sherira had relied upon the confused chronology of STVA. See Halevy, Dorot harishonim, 2:441-447; and Brody, "On the Sources for the Chronology of the Talmudic Period” [in Hebrew], 72. Many other scholars, including Jacob Efrati, Daniel Sperber, and Moshe Baer, have addressed this topic. For a summary of their views, see Brody, 77.

78 For instance, STVA and the Epistle have strikingly similar chronologies of events in the amoraic era. See Brody, "On the Sources for the Chronology of the Talmudic Period" [in Hebrew], 82-83. Yet STVA's descriptions of events during the amoraic era vary significantly from the Epistle's. See Brody, "On the Sources for the Chronology of the Talmudic Period” [in Hebrew], 82-83. For more significant differences, see Brody, 77-81; Goodblatt, Rabbinic Instruction in Sasanian Babylonia, 36-37; and Gafni, The Jews of Babylonia in the Talmudic Era [in Hebrew], 246. 79 Brody, "On the Sources for the Chronology of the Talmudic Period" [in Hebrew], 83-99.

80 Lewin, ed., Iggeret Rav Sherira Gaon, 94-99; Brody, "On the Sources for the Chronology of the Talmudic Period” [in Hebrew], 91-92.

81 See Brody, “On the Sources for the Chronology of the Talmudic Period” [in Hebrew], 92-95. 
material. ${ }^{82}$ Isaiah Gafni argues that even for the amoraic period, an era far removed from the geonic, Rav Sherira drew information from a variety of chronological lists similar to those provided in STVA, making his broad chronological framework sound and free of major flaws. ${ }^{83}$ Gafni added, however, that the Epistle's historical narrative of the talmudic period did not draw on such outside sources, and Rav Sherira played a far more active and creative role in composing that account. ${ }^{84}$ David Goodblatt has disagreed with Gafni, arguing that the long span of time between the talmudic period and the Epistle highly decreases the likelihood that Rav Sherira had access to reliable chronological sources. ${ }^{85}$ Brody, too, is skeptical about Rav Sherira's accuracy regarding events of the talmudic era, as it is difficult to assess whether there were reliable extra-talmudic sources available to him; his dating for the various events of the period, however, does not seem entirely false. Despite this ongoing scholarly controversy about the Epistle's accuracy concerning talmudic times, there is a general consensus that Rav Sherira provides extremely useful information on the post-talmudic era. ${ }^{86}$

For the late-amoraic (post-Rav-Ashi) and post-amoraic (saboraic and geonic) periods, Rav Sherira's historical account is based, to a large extent, on the records of the central Babylonian academies whose history it relates, as well as other outside sources, and it is often supported by independent evidence. ${ }^{87}$ For example, the Epistle mentions persecutions during the rule of Yazdgird II in the mid-fifth century CE, in the post-Rav-Ashi era. ${ }^{88}$ These persecutions and impositions also affected the Christians (other than Armenians), and several of the Syriac Acts of Martyrs also mention them and their impact on the Jews. ${ }^{89}$ Scholars have agreed that the Epistle's post-talmudic account draws on written records of the two

82 Brody, The Geonim of Babylonia, 23.

83 See Isaiah Gafni, “On the Talmudic Chronology in Iggeret Rav Sherira Gaon” [in Hebrew], Zion 52, no. 1 (1987).

84 Gafni, “On Talmudic Historiography in the Epistle” [in Hebrew], 293-296.

85 See Goodblatt, Rabbinic Instruction in Sasanian Babylonia, 35-40.

86 For further details on the controversy, see Brody, The Geonim of Babylonia, 23, and, especially, $23 n 17$.

87 Brody, The Geonim of Babylonia, 24-25; Gafni, "On the Talmudic Chronology in Iggeret Rav Sherira Gaon" [in Hebrew], 11.

88 Lewin, ed., Iggeret Rav Sherira Gaon, 94-96.

89 On the persecutions in the Syrian Acts of Martyrs, see Richard N. Frye, "The Political History of Iran," in The Cambridge History of Iran, vol. 3(1), ed. Ehsan Yarshater, 147; and Jacob Neusner, "Jews in Iran," 915-916. See also Gafni, "On the Talmudic Chronology in Iggeret Rav Sherira Gaon" [in Hebrew], 11-13, for further corroboration of these persecutions. 
academies and on the oral traditions then current in Rav Sherira's circles. ${ }^{90}$ Given his position as Gaon of Pumbedita, it seems clear that Rav Sherira's knowledge of events in Pumbedita was more detailed, and perhaps more accurate, than was his information on Sura. ${ }^{91}$ The core of his account is a description of the saboraic activities and a list of Saboraim with some details about them, followed by his account of the geonic period with a list of the Geonim, including in most instances the lengths of their terms. He also includes the dates on which most of the Pumbeditan Geonim assumed their positions. The Epistle's account of events is structured chronologically and divided into centuries according to the Seleucid system. The recounting of events alternates between those at Pumbedita and those at Sura.

There exist two recensions of the Epistle. Since it does not appear that Rav Sherira ever produced a second edition of his work, and there is no evidence of his revisions in either recension, Brody argues that these are "two versions of the same work." 92 The two versions differ in grammar, wording, and some substantial points of content. The most famous difference between the two versions regards Rav Sherira's response to the question of whether the Mishnah and Talmud were redacted in writing or orally. As Brody points out, the question posed to Rav Sherira assumed a written model, asking, "how was the Mishnah written? [. . .] And how was the Talmud written?"93 The two recensions have different responses. The "Spanish recension" adopts the questioner's language in reference to writing, while the "French recension" avoids any mention of writing. ${ }^{94}$ It instead uses the terms "redaction (tykken)" and "formulation (lehiburey)." 95

The misleading terms "Spanish recension" and "French recension" originate in nineteenth-century scholarship on the Epistle. They stem from the fact that medieval Spanish Jewish authorities, including Maimonides and Rabbi Shemuel Hanagid (993-1056), understood the Mishnah and Talmud to have been written down soon after the oral redaction process was completed. Scholars therefore dubbed as "Spanish" versions of the Epistle that used the term katav (Hebr., "wrote"). Versions that did not support the written model were termed "French"

90 For a discussion of whether these were familial or institutional oral traditions, see Brody, The Geonim of Babylonia, 22-23.

91 Brody, The Geonim of Babylonia, 25.

92 Brody, The Geonim of Babylonia, 21.

93 Lewin, ed., Iggeret Rav Sherira Gaon, 5-6. For Brody's point, see The Geonim of Babylonia, 21.

94 See J. N. Epstein, Introduction to Amoraitic Literature: Babylonian Talmud and Yerushalmi [in Hebrew], ed. Ezra Zion Melamed (Jerusalem: Magnes Press, 1962), 610, cited in Brody, The Geonim of Babylonia, 21.

95 For “redaction," see Lewin, ed., Iggeret Rav Sherira Gaon, 36; for “formulation," see Lewin, ed., 31. 
because they aligned with the opinion of French Jewish authorities, such as Rashi (1040-1105) and Rabbi Moses ben Jacob of Coucy (1200-1260), the author of the Sefer mitzvot gadol (The Great Book of Commandments, on the 613 commandments). In his edited Epistle, Lewin grouped the manuscripts into two parallel columns on the basis of this distinction. Lewin argued that the Spanish recension was for the most part the original version, believing that Spanish scholars were in closer contact with the Geonim and the Babylonian academies. ${ }^{96}$ Thus the French recension was, in his opinion, secondary. ${ }^{97}$

Halevy was a guiding force in Lewin's research. In his introduction to the Epistle, Lewin writes: "In particular I have expended much effort on making accessible, through brief notes, the gist of the research of the monumental Dorot harishonim as it pertains to the Epistle, so as to elucidate and clarify the words of Rav Sherira Gaon, and because this wondrous book is a great and wide sea that not everyone can navigate."98 Lewin was a follower of Halevy, despite the latter's many detractors among the practitioners of Hokhmat Yisrael. ${ }^{99}$ As discussed in the previous chapter, Lewin published volume 6 of Dorot harishonim in Jerusalem in 1939. In his Rabbanan Savora'ei vetalmudam (1937), Lewin presents a number of Halevy's theories and always praises his contribution to scholarship. ${ }^{100}$ Halevy, on the other hand, was not as complimentary of Lewin and his critical approach. As described later in this chapter, Halevy did not approve of Lewin's reliance on manuscripts and did not utilize them in his own research.

Both the division of the text of the Epistle into a Spanish and a French rescension and the preference for the Spanish version have been challenged in recent scholarship. The nineteenth-century division was predicated not upon any solid evidence but, rather, upon the assumption that medieval scholars had superimposed their own views on the Babylonian Geonim and had altered the work to fit their preconceived ideas. ${ }^{101}$ In addition, the notion that the French recension was developed by French scholars is quite problematic, given the evidence found in the Cairo Genizah. Brody has pointed out that it is

96 See Lewin, introduction to Iggeret Rav Sherira Gaon, ed. Lewin, xlvii and lvii-lx.

97 See Lewin, introduction to Iggeret Rav Sherira Gaon, ed. Lewin, xlvii-l.

98 Lewin, introduction to Iggeret Rav Sherira Gaon, ed. Lewin, xlv.

99 For more details, see Asaf Yedidya, “Benjamin Menashe Lewin” [in Hebrew], 140-141.

100 For notable examples, see Binyamin M. Lewin, Rabbanan Savora'ei vetalmudam (Jerusalem: Ahi'ever, 1937), 3, 7, and 54.

101 See Lewin, introduction to Iggeret Rav Sherira Gaon, ed. Lewin, xlvii-li; and Brody, The Geonim of Babylonia, 22. 
"particularly striking and significant [. . . that all the fragments of the Epistle found in the Cairo Genizah belong to the so-called French recension!"102 Brody concludes that textual analysis shows that the French recension is the original. Its Aramaic has more features in common with geonic Aramaic, and it preserves the original text. Difficult readings, often interpreted and explained away in the Spanish version, are left in place in the French version, suggesting that, according to the principle of lectio difficilior potior (the more difficult reading is [the] better [one]), the French recension is the one closer to the original. ${ }^{103}$ Moreover, Yaakov Nahum Halevi (J. N.) Epstein (1878-1952) noted that, while the underlying text takes for granted an oral redaction, the conception of a written redaction has clearly been superimposed on it. ${ }^{104}$ Both recensions have this same critical passage, demonstrating that Rav Sherira assumed an oral model: "And as for what you wrote: 'How were the Mishnah and the Talmud written?' The Talmud and the Mishnah were not written, but redacted, and the rabbis are careful to recite them orally." The Spanish recension even adds, "and not from written copies." 105 It is thus evident that any allusions to a written redaction are later additions, and so the French edition, which maintains the oral redaction model throughout the text, appears to be more reliable in maintaining the most accurate possible version of the Epistle.

\subsubsection{The Sefer haqabbalah of Abraham Ibn Daud}

Sefer haqabbalah (The Book of Tradition) of Abraham Ibn Daud (ca. 1110-1180), completed in Toledo in 1161, provides another major contribution to the chronology of the talmudic period. ${ }^{106}$ Sefer haqabbalah includes much of the same material as the Epistle, but the two works nonetheless differ significantly. The texts disagree on the date of death of Ravina bar Huna and, therefore, on the date of the redaction of the Talmud. While the Epistle has the date of Ravina bar Huna's death and the concurrent closing of hora'ah in 500/501, Sefer haqabbalah has it

102 Brody, The Geonim of Babylonia, 22.

103 In a few instances, however, there are original readings in the Spanish recension. See examples in Epstein, Introduction to Amoraitic Literature [in Hebrew], 614-615, cited in Brody, The Geonim of Babylonia, 22. See also Halivni, The Formation of the Babylonian Talmud, $25 \mathrm{n} 71$.

104 See Epstein, Introduction to Amoraitic Literature [in Hebrew], 610-615, cited in Brody, The Geonim of Babylonia, 22.

105 Brody, The Geonim of Babylonia, 22; Lewin, ed., Iggeret Rav Sherira Gaon, 71, which Brody cites there.

106 The date of the composition of the work is noted by Ibn Daud himself. See Ibn Daud, The Book of Tradition, ed. Cohen, 43. 
as 474/475. ${ }^{107}$ Ibn Daud's survey of the geonic period also departs from the Epistle's account, and modern research has shown it to be replete with problems and inaccuracies. His list of the first three generations of Geonim is indicative of Ibn Daud's problems: he placed the Geonim of Sura in Pumbedita and vice versa. ${ }^{108}$ Gerson Cohen has said that modern scholarship on geonic history has largely supported Rav Sherira but not Ibn Daud, and thus one cannot count on "the credibility of Ibn Daud whenever he makes an otherwise unattested statement." ${ }^{109}$ Cohen argues that Ibn Daud was informed by one post-talmudic work, which was similar to the Epistle, and that he also incorporated material from other works and rearranged the Epistle's material to create his own chronology. ${ }^{110}$

\subsubsection{The Seder haqabbalah of Rabbi Menahem Meiri}

Another chronological work that should be mentioned in this context is Seder haqabbalah, by the Provençal scholar Rabbi Menahem Meiri (1249-1316). ${ }^{111}$ Meiri was unique among the high-medieval rabbinic scholars [Rishonim] in offering a historiographical work dedicated to a comprehensive, cohesive chronology of the redaction process; the others included their theories about the redaction of the Talmud in their commentaries on the Talmud or as introductions to their halakhic works. (See, for example, Maimonides's summary of the issue in the introduction to his Mishneh Torah and to his commentary on the Mishnah. ${ }^{112}$ See also Rashi to b. Bava Metzi’a 86a, s.v. sof.) Although Meiri's work was also published as an introduction to his commentary to m. Avot (Ethics of the Fathers), it is unique in that it is an historiographical work in the genre of shalshelet haqabbalah. Unlike the introductions of the other Rishonim, Seder haqabbalah is actually an independent work appended to m. Avot rather than just an introduction. It precisely lays out the chain of tradition from Adam until

107 Lewin, ed., Iggeret Rav Sherira Gaon, 95; Ibn Daud, The Book of Tradition, ed. Cohen, 42.

108 See Ibn Daud, The Book of Tradition, ed. Cohen, 177-179.

109 Ibn Daud, The Book of Tradition, ed. Cohen, 178.

110 Ibn Daud, The Book of Tradition, ed. Cohen, 186-188.

111 Menahem Meiri, Seder haqabbalah: History of the Oral Law and of Early Rabbinic Scholarship by Rabbi Menahem HaMeiri [in Hebrew], ed. Shlomo Zalman Havlin (Jerusalem: Ofeq, 1995).

112 On his introduction to the Mishnah, see Maimonides, Mishnah: Im pirush Moshe ben Maimon, ed. and trans. Josef David Kapach; see also Maimonides, introduction to the Mishneh Torah, Shabtai Frankel ed., 1:1-4. 
Meiri's own lifetime, with details about the people as well a thorough analysis of their works. Meiri also includes a brief summary of Jewish history from the creation of the world until his own days: "In [my commentary on] this Mishnah, I will elaborate upon the entire chain of tradition, from the day God created man until today." ${ }^{113}$ His work expands beyond a pure historiographical account into historiosophy - the analysis of events and of the sages' character. ${ }^{114}$ Meiri's sources for the historiography of the talmudic period come primarily from rabbinic literature; Ibn Daud's Sefer haqabbalah serves as his main source for the chronology of the post-talmudic period, although it is possible that he also sometimes relied on a Book of Tradition authored by Rabbi Nissim ben Jacob, also known as Rabbi Nissim Gaon (990-1062). This work is known to have existed, but no extant copies of it have been discovered. ${ }^{115}$ Though Meiri's account of the formation of the Talmud did not add any significantly reliable original perspectives to the literature on the subject, his analysis of the process does add some important ideas. ${ }^{116}$ For instance, when describing the era of the Saboraim, he notes, "For all the days of Rabbanan Savora'ei, regal honor was accorded the heads of the academy. They would still teach the Talmud orally, since no composition of the Talmud had been widely disseminated yet." ${ }^{117}$ His view is consistent with Halevy's opinion, to be discussed later, that the Talmud continued to be transmitted orally during saboraic times, even after a written text was available.

\subsection{Halevy's assessment of the sources}

Halevy did not view any of the shalshelet haqabbalah literature in a particularly positive light. He characterized the text of STVA as corrupt and its material as disjointed. He thought that it was a compilation of several chronologies and not the work of one author. ${ }^{118}$ Unlike Graetz, Halevy did not believe that the Epistle used STVA as a source. ${ }^{119}$ He preferred the Epistle, and he used it as the basis of his own chronology in Dorot harishonim, writing: "In all matters related

113 Meiri, Seder haqabbalah, ed. Havlin, 7.

114 Shelomo Zalman Havlin, introduction to Seder haqabbalah, ed. Havlin, xiv.

115 Meiri specifically mentions Rav Nissim Gaon only once in his work. See Havlin, introduction to Seder haqabbalah, ed. Havlin, xxiv-xxviii.

116 On the lack of significant originality, see Havlin, introduction to Seder haqabbalah, ed. Havlin, xlvi.

117 Meiri, Seder haqabbalah, ed. Havlin, 114.

118 Halevy, Dorot harishonim, 2:227n28 and 2:443n102.

119 Halevy, Dorot harishonim, 2:442-447. 
to Babylonia, Rav Sherira Gaon's words are reasoned and verified."120 When contrasting it to STVA, Halevy remarked, in his unique style, "If we compare the clear and organized words of Rav Sherira Gaon to a human being, can the words of [STVA] even be considered simian?"121

Halevy used various editions of the Epistle: the first edition, published by Rabbi Samuel Shalom in Constantinople in 1566 as part of Abraham Zacuto's Sefer hayuhasin; Baer Goldberg's Hefets matmonim edition of 1845, based on Ms. Berlin; and Adolf Neubauer's 1888 Seder hahakhamim edition. ${ }^{122}$ These were not critical editions, and all had many errors and misprints, which Halevy corrected throughout. ${ }^{123}$ As he was very skeptical of recent editions relying on newly found manuscripts, Halevy thought that Shalom's edition of 1566 was the most accurate. In his view, Shalom was very knowledgeable and had had many manuscripts available to him. Although Halevy acknowledged the myriad mistakes and misprints in Shalom's edition, he believed that the other editions were based on later manuscripts with which later scribes had tampered, making them less reliable. ${ }^{124}$ As with talmudic manuscripts, moreover, Halevy rejected the utilization of manuscripts of the Epistle in the publication of a critical edition. In a letter to his son Shemuel, he expressed his preference for the printed editions of the Epistle: "Your honorable friend Mr. Lewin is afflicted with the same disease as all those who think that manuscripts are sacred, having been written by angels, and contain no scribal errors. [. . . I In truth, manuscripts are more susceptible to errors than the printed editions of a publishing house, which has dedicated editors." 125 Halevy always preferred correcting the printed text himself when he believed the extant version posed difficulties. Such an approach to emendation also gave him latitude to correct any text that did not fit his theories. In keeping with his determined apologetic approach,

120 Halevy, Dorot harishonim, 2:163.

121 Halevy, Dorot harishonim, 2:442.

122 For more on Shalom's 1566 Constantinople edition, see Lewin, introduction to Iggeret Rav Sherira Gaon, ed. Lewin, xvii-xx. For more on Goldberg's 1845 Berlin edition, see Lewin, ed., xx-xxv. See also Halevy, Dorot harishonim, 2:181, 2:496, 2:497, 2:503, and 3:173-174. For more on Neubauer's Oxford 1888 edition, see Lewin, introduction to Iggeret Rav Sherira Gaon, ed. Lewin, xxxiii-xxxv. See also Halevy, 2:474n118, 2:496-497, 2:503, and 3:173-174.

123 For notable examples, see Halevy, Dorot harishonim, 2:211-216, 2:497 and 2:497n134, 2:504, 2:599, 3:7-9, 3:64, and 3:88.

124 Halevy, Dorot harishonim, 2:215n18. He notes such later emendations throughout his work. For examples, see Halevy, 2:504, 2:593, 3:10, and 3:33. Halevy nonetheless at times emends the 1566 edition based on the other editions. See Halevy, 3:173-174.

125 Halevy, Iggerot Rabbi Yitzhak Isaac Halevy, 147 (letter 76). 
his creative emendations, which can be significant, at times contradict all textual witnesses and the view of early rabbinic authorities. These numerous emendations to the Talmud are dispersed throughout his work. ${ }^{126}$

One of Halevy's greatest points of agreement with Rav Sherira concerned the Epistle's account of the leading role of the academy of Sura at the time of the end of hora'ah. ${ }^{127}$ But Halevy disagreed with the Epistle's dating on a number of significant points, including regarding the periodization of the saboraic era - and, in fact, whether there even was a saboraic era clearly distinct from the geonic era, since the Epistle seems to imply in several instances that there was not a clean break between them. ${ }^{128}$ In several cases, Halevy contradicted Rav Sherira, often using dating matching Ibn Daud's in Sefer haqabbalah. Regarding the death of Ravina bar Huna and the ensuing end of hora'ah, Halevy went so far as to emend the text of the Epistle, antedating the death by 25 years. Halevy's critics, and even his own son, harshly criticized him for this action, as will be discussed in chapter $4 .{ }^{129}$

Halevy's use of some dates from Ibn Daud in his own chronology should not be seen as an indication that he usually considered Sefer haqabbalah to be a more reliable source than the Epistle, though he occasionally thought that. ${ }^{130}$ Halevy acknowledged Sefer haqabbalah's weaknesses, especially for one time period: "It is difficult to rely on what Ibn Daud says about the amoraic era, since nothing he says is precise." ${ }^{131}$ In his view, the errors in the text of Sefer haqabbalah were due to faulty sources. ${ }^{132}$ For the late- and post-amoraic era, however, Halevy thought that Sefer haqabbalah provided valuable independent information, since it recorded Suran traditions, while Rav Sherira presented Pumbeditan traditions. ${ }^{133}$ For ideological reasons, it was imperative for Halevy that Ibn Daud had not seen the Epistle, since that meant that Sefer haqabbalah represented a totally independent source, from which Halevy could adduce independent evidence to support his views, and, at times, even to emend the text of the Epistle. ${ }^{134}$ Halevy employed this strategy to amend the date of Ravina's death (as will be discussed in chapter 4), to identify members of his beit

126 For a notable example, see Halevy, Dorot harishonim, 2:437-439.

127 Halevy, Dorot harishonim, 3:26-27. See chapter 4 for a fuller discussion of this issue.

128 See chapter 4 for a more detailed discussion of the Epistle's dating of the geonic era.

129 On the criticism by Halevy's son, see Halevy, Iggerot Rabbi Yitzhak Isaac Halevy, 147-148 (letter 76).

130 See examples in Halevy, Dorot harishonim, 2:597, 3:7, 3:15, 3:88, 3:101, and 3:175.

131 Halevy, Dorot harishonim, 2:499.

132 Halevy, Dorot harishonim, 3:55 and 3:178.

133 Halevy, Dorot harishonim, 3:35, 3:35n11, and 3:55.

134 For notable examples, see Halevy, Dorot harishonim, 2:601 and 3:101. 
hava'ad, to create his timeline of Saboraim, and to date the transition between their era and that of the Geonim, which, according to Halevy, varied depending on whether one was in Sura or Pumbedita. ${ }^{135}$

Halevy does not quote Meiri's Seder haqabbalah. Although the work had been published in 1821 in Salonika by Rabbi Hayyim Palagi (1788-1868), almost the entire edition was burned, leaving only a few remaining copies, which meant it was unknown to many rabbinic scholars. ${ }^{136}$ Although Halevy generally had a negative view of the historical acumen of the Rishonim, since they did not write dedicated works of history, Seder haqabbalah is quite different from the others, since, as discussed above, it presents a complete shalshelet haqabbalah. ${ }^{137}$ Yet it is not surprising that Halevy did not quote it, due to its scarcity, though it had been reprinted in Vienna in $1854 .{ }^{138}$ It is quite unfortunate that Halevy did not have access to it, since it is precisely the type of historiography that he remarked was missing from the works of other medieval scholars, and, on several occasions, his ideas matched Meiri's. For instance, both Meiri and Halevy thought that the Talmud was taught orally throughout the saboraic period, even when written exemplars were already available, as will be discussed further in chapter $4 .^{139}$ One further instance of agreement was the identification of Rav Ahai, who is mentioned in b. Ketubbot 2b and b. Zevahim 102b. Both Meiri and Halevy identified him as Rav Ahai son of Rav Huna, who was mentioned in the Epistle among the sages of the first generation of Saboraim. Their shared view contrasted with that of Tosafot, who claimed that Rashi's grandson, Rabbi Shemuel ben Meir (RaSHBaM, ca. 1080-85-ca. 1174) assumed that Rav Ahai was the eighth-century Gaon Rav Ahai of Sabha, as will be discussed in chapter $4 .{ }^{140}$

Halevy's criticism of the shalshelet haqabbalah literature arose from two primary factors: historiography and ideology. As discussed in chapter 1, Halevy

135 On emending the date of Ravina's death, see Halevy, Dorot harishonim, 3:7-9 and 3:15. On the members of the beit hava'ad, see Halevy, 2:601. On the timeline of the Saboraim, see Halevy, 3:28, 3:33-34, and 3:178. On dating the transition between Saboraim and Geonim, see Halevy, 3:33-36, 3:54-56, and 3:171-175.

136 Menahem Meiri, Beit Avot, ed. Eliyahu Wolf Rosenberg (Warsaw: Rosenberg, 1920), 3.

137 See Halevy, Dorot harishonim, 2:117, 2:216, 2:228, 2:241, 2:262, 2:264n5, 2:318, 2:448n105, 2:476, 2:476n120, and 3:54.

138 Meiri, Beit Avot, 3.

139 Meiri, Seder haqabbalah, 114; Halevy, Dorot harishonim, 3:49.

140 Meiri, Seder haqabbalah, 113 and 113n501; Halevy, Dorot harishonim, 3:57. On Rashbam's dates, see Avraham Grossman and Israel Moses Ta-Shma, "Samuel ben Meir," in Encyclopaedia Judaica, edited by Michael Berenbaum and Fred Skolnik, accessed 1 July 2020, https://yulib002. mc.yu.edu:2821/apps/doc/CX2587517439/GVRL?u=nysl_me_yeshival\&sid=GVRL\&xid=008565c2. 
saw himself as a scholar in the tradition of Hokhmat Yisrael, a man who prized objectivity and the careful reading of primary sources. On the Epistle, he said: "We have already noted the obvious fact that in regard to the era of Tannaim and Amoraim, it is imperative to return to the sources and clarify everything through the words of the Talmud using clear evidence, irrespective of the accuracy of the Epistle's text." 141

Despite Halevy's call for, and use of, modern scholarly practices, and his commitment to using the Talmud, the Epistle, and Sefer haqabbalah to construct his chronology, his agenda - proving certain points that supported his political ideology - often interfered with his implementing those practices in his own work. The emendation of the Epistle regarding the date of the closing of the Talmud is only the most serious example of Halevy's willingness to bend the sources in order to reach a predetermined conclusion.

\subsection{Conclusion}

In Halevy's time, as is mostly still true today, the shalshelet haquabbalah literature described in this chapter, along with minimal internal evidence from the Talmud, were the only pre-modern sources on which a scholar could rely in attempting to reconstruct the process of the formation of the Talmud. Current scholars, including Robert Brody, Isaiah Gafni, and David Weiss Halivni, continue to draw on these works. ${ }^{142}$ As Halevy and some of his contemporaries realized, these works lack historical sophistication. Their authors were not historians and thus did not prioritize getting to the historical truth of the Talmud's formation. Halevy saw the weaknesses of STVA, the Epistle, and Sefer haqabbalah, and he claimed that he would improve them in his own chronology as set out in Dorot harishonim. Yet, though he professed interest in objectivity and the thorough investigation of primary sources, and though he did make some valuable contributions to the history of the formation of the Bavli, his determination to make certain political and apologetic points about the early rabbinic world often interfered with his willingness to use modern historical methods, as will be discussed in the next two chapters.

141 Halevy, Dorot harishonim, 2:215n17.

142 See Brody, The Geonim of Babylonia; Brody, “The Epistle of Sherira Gaon,” in Rabbinic Texts and the History of Late-Roman Palestine, ed. Martin Goodman and Philip Alexander, Proceedings of the British Academy 165 (Oxford: Oxford University Press, 2010); Gafni, The Jews of Babylonia [in Hebrew]; Gafni, "On Talmudic Historiography in the Epistle" [in Hebrew]; Gafni, “On the Talmudic Chronology in Iggeret Rav Sherira Gaon” [in Hebrew]; and David Weiss Halivni, The Formation of the Babylonian Talmud. 